\title{
Некоторые вопросы математического образования в кадетском корпусе.
}

\author{
Двойневская Н.А. \\ КОУ ВО «Горожанский казачий кадетский \\ корпус» Воронежская обл., Рамонский район, \\ e-mail:gsshi@yandex.ru
}

"Школа долюна в первую очередь

учить детей мыслить - причем,

всех детей, без всякого исключения,

несмотря на разное имущественное

и социальное положение семей.

а также наследственных задатков детей"

В. В. Давыдов.

В ноябре прошлого учебного года в КОУ $\mathrm{BO}$ "Горожанский казачий кадетский корпус" состоялось тематическое методическое объединение учителей математики, физики, информатики, на котором присутствовали не только учителя - предметники названных дисциплин, но и приглашённые коллеги - учителя иностранного языка, представители психологической службы, все, кто не равнодушен к проблемам современной школы, и в частности, кадетского корпуса. Здесь речь шла об образовательных стандартах, которые рассматриваются сегодня как средство обеспечения стабильности качества образования. Стандарт первого поколения, принятый в 2004 г. в результате сложившейся в начале 90-х годов прошлого века ситуации многообразия образовательных систем являлся прогрессивным шагом на пути модернизации отечественного образования, переход от "консервации" к развитию образования, внедрение идей личностно ориентированной педагогики, предполагающих снятие перегрузки обучающихся, введение профильного обучения на старшей ступени школы, с утверждением вариативности, дифференциации образования. На смену 
ГОСам пришли стандарты второго поколения (ФГОС) основного общего и среднего (полного) общего образования, утверждённые приказами Минобразования и науки РФ от 2010 г. и 2012 г.. В 2015 году все школы, прошедшие государственную аккредитацию, перешли на использование новых технологий, продиктованных новыми стандартами. Руководитель МО Двойневская Наталья Анатольевна рассказала о новых требованиях к обучению учащихся, обратила внимание на наличие автоматизированного рабочего места как обязательного условия работы учителя, оборудованного компьютером, принтером, проектором, экраном. На уроках должны использоваться презентации, фрагменты фильмов, специальный раздаточный материал для работы в парах, группах, современный УМК должен включать в себя учебник с грифом ФГОС, контрольные и самостоятельные работы, устные упражнения, рабочую тетрадь, методические разработки, диски, тематические тесты. Были показаны образцы таких учебников, содержащих рубрики: "Ищем информацию", "Исследуем", "Доказываем", "Придумываем задачу", "Задачи-шутки", "Историческая справка". Цель ФГОС подготовка детей России, способных проходить онлайн-тестирование на уровне мирового сообщества. И что бы этого добиться, необходимы новые технологии в образовании. Стандарты второго поколения требуют смены репродуктивного метода обучения - метода, где применение изученного осуществляется на основе образца или правила, на проблемный, поисковый, исследовательский методы обучения, которые заключаются в организации активного поиска решения задач под руководством педагога на основе указаний в учебном пособии; где после анализа материала, постановки проблем и задач и краткого инструктажа обучаемые самостоятельно изучают литературу, ведут наблюдения и измерения, где инициатива, самостоятельность детей, творческий поиск проявляются наиболее полно. Вниманию присутствующих была предложена презентация "Новые технологии в образовании", в которой речь шла о таких технологиях во ФГОСах, как интеллект-карты, технология развития, критического 
мышления. Материал презентации посвящён использованию новейшего в образовании, совершенно другому подходу в изложении материала, другой структуре урока, и даже в отношении к теме урока, которая определяется самими учениками. Определить тему урока было предложено участникам заседания. Каждый из присутствующих побывал в роли активного ученика, сменив позицию пассивного слушателя. Успешно справившись с заданием, назвали тему урока математики "Рациональные числа".

В прежних стандартах имели место такие дидактические понятия и в такой последовательности, знания, умения, навыки. ФГОСы предлагают развивать навыки, умения, знания, действия обучающегося, самостоятельно добывающего знания, когда учитель выступает в роли организатора, направляющего деятельность учеников. Появляется такое понятие как универсальные учебные действия (УУД). Среди которых различают:1) личностные (умения осознавать личный прогресс, формировать личностные качества через рефлексию, уметь работать с информацией),2) регулятивные(регулировать себя, самоанализировать, оценивать, отслеживать динамику роста, сколько ошибок было, сколько стало, 3 ) общепознавательные (развивать желание учиться), 4)коммуникативные (уметь работать в парах, группах, доказывать свою точку зрения...).

Методологической основой стандартов второго поколения является системно - деятельностный подход, который обеспечивает формирование готовности обучающихся к саморазвитию и непрерывному образованию, воспитанию и социализации обучающихся, т. е. готовности к самостоятельной успешной жизни.

Наряду с межпредметными связями появляется новое понятие метапредметные результаты образовательной деятельности. Межпредметные связи получили широкое распространение в учебном процессе; метапредметные связи - с введением ФГОС второго поколения начинают играть важную роль в образовательном процессе. Интегрированные 
уроки развивают познавательный интерес учащихся, побуждают к активному познанию окружающей действительности, формируют у учащихся метапредметные учебно - информационные умения. Каждый из присутствующих предлагал свои примеры интегративных технологий. Об информационных технологиях, их связях с экологией, на примере структуры воды, её способности считывать информацию, рассказал учитель географии и информатики Маркин Алексей Иванович. Учитель английского языка Кругликов Геннадий Юрьевич продемонстрировал разработку программы, которая позволяет проверить знание перевода английских слов на русский язык с помощью компьютера, учитель музыки Демидова Наталия Валерьевна и учитель математики Двойневская Наталья Анатольевна предложили свою разработку интегрированного урока "математика - музыка" по теме "Обыкновенные дроби", который показывает взаимосвязь между дробями в математике и долями в музыке, что придаёт звучанию соответствующий окрас, темп, ритм. Присутствующие оценили открытие ученых, которые переложили число П на музыку (каждой цифре этой бесконечной непериодической десятичной дроби поставили в соответствие соответствующую ноту тональности ля минор) и получили гармоничную мелодию, заставляющую задуматься о совершенстве мира. Связь математики и этики, которую изучают кадеты старших классов, приходится наблюдать на уроках знакомства с великими мыслителями прошлого - Лейбницем, Пифагором, Фалесом, Аристотелем, которые являлись выдающимися математиками, открывателями в области геометрии, интегральнодифференциальных вычислений, одновременно авторами философских трудов о всемогуществе человеческого разума. Учителя английского языка поддержали предложение о подготовке учащихся корпуса к представлению и защите проекта по математике на английском языке в МБОУЛ "ВУВК им. А.П. Киселёва".

Для кадетского корпуса важным является воспитание сознательной дисциплины кадет. С докладом о поведении учащихся в свете особенностей 
возрастной психологии, о локус-контроле, астернальном и инфернальном типе поведения выступила педагог-психолог Воронина Екатерина Александровна . В заключении заседания были подведены итоги проведения школьного этапа Всероссийской предметной олимпиады по математике, физике, информатике. Лучшими по корпусу оказались результаты олимпиады по информатике. В олимпиаде по математике приняло участие 38 кадет, среди которых одиннадцать человек - победители и призёры. Учитель математики Двойневская Наталья Анатольевна выразила своё мнение о необходимости больше решать задач на развитие пространственного воображения и логического мышления, обратить внимание на знание математических формул, основ теории вероятности, геометрических задач, построение графиков функций, содержащих модули. В заключении заседания Двойневская Наталья Анатольевна сделала ссылку на приказ Министерства образования и науки Российской Федерации от 7 апреля 2014 г. № 276 «Об утверждении порядка проведения аттестации педагогических работников организаций, осуществляющих образовательную деятельность», рассказала о порядке и сроках проведения аттестации педагогических работников, назвала необходимые документы, указала на необходимость аттестации, что требует положение - документ "Профстандарт педагога".

\section{Список литературы:}

1. Федеральный государственный общеобразовательный стандарт основного общего образования (Утвержден приказом Министерства образования и науки Российской Федерации от 17 декабря 2010г., № 1897).-50 с.

2. Федеральный закон «Об образовании в Российской Федерации» от 29 декабря 2012 г. № 273-Ф3.

3. Нацпроект «Образование» (Электронный ресурс)//mon.gov.ru/proekt/ideology. 